\title{
The Effect of Gamma $(\gamma)$ Irradiation to inactivate Escherichia coli in Contaminated water
}

\author{
H Ahari', M Alinejad Dizaj', S Paidari ${ }^{3}$, A Anvar ${ }^{4 *}$ \\ ${ }^{1}$ Assistant Professor, Department of Food Science and Technology Science and Research Branch, Islamic \\ Azad University, Tehran, Iran \\ ${ }^{2}$ Chronic Respiratory Diseases Research Center, National Research Institute of Tuberculosis and Lung \\ Diseases (NRITLD), Shahid Beheshti University of Medical Sciences, Tehran, Iran. \\ ${ }^{3}$ Department of Food Science. Technology Science and Research Branch, Islamic Azad University, \\ Tehran, Iran \\ ${ }^{4}$ Assistant Professor, Department of Hygiene, Science and Research Branch, Islamic Azad University, \\ Tehran, Iran.
}

Received: January 2015 Accepted: April 2015

\begin{abstract}
Current study was conducted to evaluate the efficacy of gamma irradiation to eradication of microbial contaminants from food industry water resources. Water samples were collected from food industries located around Tehran, capital of Iran. Samples from three major resources of food industry water system; Well, Tank and Recycled water were collected and one part of the samples irradiated with ${ }^{137} \mathrm{Cs}$ gamma radiator.

*Correspondence: ${ }^{4}$ Assistant Professor, Department of Hygiene, Science and Research Branch, Islamic Azad University, Tehran, Iran. (e-mail: saaa4824@gmail.com).
\end{abstract} Treated and untreated samples were tested by standard Multiple-tubes fermentation technique for detection of coliform bacteria and MPN indexes were calculated. Gamma irradiation had killing effect on coliforms and leads to noticeable reduction in MPN indexes of treated water samples compared to untreated ones. With few modifications in radiation dose, it is expected to implant portable gamma radiators to treatment of water in food industry section.

Keywords: food industry, gamma-irradiation, water treatment, coliforms 


\section{Introduction}

There has been a vast need for inactivation of different kinds of pathogens from drinking and waste waters. Traditionally, cholorization, ozonization and UV radiation processes have been used as the most common methods of disinfecting waters whilst Gamma radiation is being used more frequently due to concerns over by-products made by conventional methods such as cholorization and their contribution to increment of cancer risks and mortality. Between these pathogens (Thompson 2000) presence of Ecoli in water is conducted as the first source of water pollution.According to international standards Ecoliis transferred through oral and fecal contaminations and contaminated foods to human beings, in human body. It is presented as opportunist pathogen and cause urinal tract infections, septicemia, septic shock, new born meningitis as well as bird coli bacillus, pericardiagranoluma and salpenjite in birds and poultries(She, Shi, Xu, Zhou, Li, Tian, Li, Li, Dong \& Ren 2016; Smith, Seymour, Moccia \& Mothersill 2016; Zhang T. Y., Lin, Xu, Xia, Tian \& Gao 2016a).

Gamma rays are high energy photons released from nucleus during radioactive delay process and has been used in a variety of situations for many years to inactivate microorganisms e.g. medical products, food products and municipal sewages and sludge sewages. These days radiation method is used as portable method, which does not cause ionization of water and also any changes in physical and chemical properties of water. One of the main advantages of Gamma radiation consists of the fact that since irradiation is a physical process, no chemicals have to be added (Vilela, Oliveira, Vicentini, Casagrande, Verri, Cunha \& Fonseca 2016; Zevallos-Concha, Nunez, Gasco, Vasquez, Quispe \& Gonzales 2016; Zhu, Liu, Yu, Zhou \& Yan 2016).

Microbial disinfection resulting from Gamma radiation is believed result from two general classes of reactions. The first direct ionization of Gamma photon energy and the second is, gamma radiation of aqueous material produces highly reactive unstable intermediates such as hydroxyl radicals, hydrogen atoms, and hydrated electrons. These highly reactive intermediates can cause chemical changes in the aqueous system and within microorganisms resulting in damage to the organisms in the system which, in turn, destroy particle associated micro-organisms(Hayati, Rezvani, Morsali \& Retailleau 2017; Shirai, Miura, Yoshida, Yoshino, Ito, Yoshinari \& Yajima 2016; Thang, Au, Rakovski \& Prakash 2016).

\section{Material and Methods}

In this study, lactose broth, Brilliant Green Bile broth $2 \%$, EMB agar media have been used for cultivation of bacteria as well as Selective media (citrate, urea, MRVP, SIM, TST).Also Durham tubes were utilized to detect gas production.

\section{Sampling}

100 water samplesfrom poultry farm destinies wells, and tank water, were collected using sterile 
dishes (with $100 \mathrm{ml}$ volume)near flame, from different a areas throughout the year, near flame samples were transferred to veterinary diagnosticlaboratory in less than 30 minute by help of ice. About $1 / 3$ of samples were transferred to microbiology laboratory of veterinary college, Urumia university (tap and air pump were disinfected to avoid secondary pollution). Samples were divided into two groups, first group were directly transferred to microbiology laboratory for cultural process and were cultured on EMB medium.

Second group were transferred to nuclear physics laboratory and they were irradiated by $\operatorname{cs}(\operatorname{cs} 137)$ with 20 milicurieactivity level for 6 hours The radiation device had 12 years half-life and was containedby lead walls all over radiation source.

After radiation samples were rapidly transferred to microbiology laboratory using ice to perform cultural and other test activities as mentioned for previous group. Then using 9 test tubes method they were tested.In this method at the first, lactose broth medium was made, first 3 test tubes contained strong medium ( $26 \mathrm{~g} / \mathrm{lit})$ and the other 6 remaining tubes contained weak medium (13 g/lit). All test tubes were contained small Durham tubes in a reverse form,therefore all tubes were contained $10 \mathrm{ml}$ lactose broth.

$10 \mathrm{ml}$ water was added to the first 3 tubes $1 \mathrm{ml}$ to the next 3 tubes and $0.1 \mathrm{ml}$ water sample to the last 3 tubes. All tubes were incubated at 37 for $24 \mathrm{~h}$. Tubes that did not contain gas in their
Durham tubes were incubated for another 24 hours to obtain more assurance. if after 48 hours gas wasnot present it was countedas negative result otherwise, presence of gas in Durham tubes cause conducting of MPN testing for coli form counting. According to obtained result, 4 tubes werecontained gas bubbles which were separated from the other tubes and $10 \mathrm{ml}$ 2\%BGB broth was addedto them and 3-4 $\mathrm{ml}$ of sample from contaminated lactose broth tubes were added to the $2 \%$ BGB broth containing mj test tubes.

Presence of contamination caused gas production in Durham tubes. sample form contamination BGBbroth tubes were culture on EMB agarby slenle culture loop to observe colonies withmetallic greenish color if greenish color was not observe thenselective tests (TSI, SIM, MRVP), were conducted.

It is important to know that entrobacter kits are used instead of selective tests in these days. The other sample groups were under gone same process as mentioned above after radiation and transferring to the lab.

\section{Results}

According to obtained results, 3- $\delta$ radiated water samples out of all water samples, showed $42 \%$ contamination reduction. Radiationby 20 milicurie was effective on this pathogen (Tables $1-2)$. 
H Ahari et al., Gamma irradiation inactivates E. coli

Table 1 The number of colonies that obtained from the water that is not affected by Gama ray

\begin{tabular}{|c|c|c|c|c|c|}
\hline & & $\begin{array}{l}\text { pipes with bubble } \\
\text { with } 10 \mathrm{cc} \text { of } \\
\text { doubtful water }\end{array}$ & $\begin{array}{c}\text { pipes with bubble } \\
\text { with 1cc of } \\
\text { doubtful water }\end{array}$ & $\begin{array}{l}\text { pipes with bubble } \\
\text { with } 0.1 \text { cc of } \\
\text { doubtful water }\end{array}$ & mpn \\
\hline \multirow{3}{*}{$\begin{array}{c}\text { A samples of } \\
\text { waterof the watering } \\
\text { Trough }\end{array}$} & Sample \# 1 & 3 & 3 & 3 & 1100 \\
\hline & Sample \# 2 & 3 & 3 & 1 & 460 \\
\hline & Sample \# 3 & 3 & 3 & 2 & 1100 \\
\hline \multirow{3}{*}{$\begin{array}{l}\text { B samples of water } \\
\text { of the source }\end{array}$} & Sample \# 1 & 3 & 2 & 1 & 150 \\
\hline & Sample \# 2 & 3 & 1 & 0 & 43 \\
\hline & Sample \# 3 & 3 & 2 & 0 & 93 \\
\hline \multirow{3}{*}{$\begin{array}{l}\text { C samples of water } \\
\text { of the village's well }\end{array}$} & Sample \# 1 & 3 & 0 & 2 & 64 \\
\hline & Sample \# 2 & 2 & 0 & 0 & 23 \\
\hline & Sample \# 3 & 2 & 3 & 2 & 44 \\
\hline
\end{tabular}

As Tables 1 shows, the maximum colonies that was found in watering Trough which had not been exposed to radiationwas 1100 colonies and the minimum was 460 colonies. The maximum number of colonies that was found in Source water, which had not been exposed to radiation was 150 colonies and the minimum was 43 colonies. Finally, maximum number of colonies detected in village's well was 64 whereas the minimum was 44 colonies.

Table 2 The number of colonies that obtained from the water that affected with the Gama ray

\begin{tabular}{|c|c|c|c|c|c|}
\hline & & $\begin{array}{c}\text { pipes with } \\
\text { bubble } \\
\text { with } 10 \mathrm{cc} \text { of } \\
\text { doubtful water }\end{array}$ & $\begin{array}{c}\text { pipes with } \\
\text { bubble } \\
\text { with 1cc of } \\
\text { doubtful water }\end{array}$ & $\begin{array}{c}\text { pipes with } \\
\text { bubble } \\
\text { with } 0.1 \text { cc of } \\
\text { doubtful water }\end{array}$ & $\mathrm{mpn}$ \\
\hline \multirow{3}{*}{$\begin{array}{l}\text { A samples of } \\
\text { waterof the } \\
\text { watering } \\
\text { Trough }\end{array}$} & Sample \# 1 & 3 & 3 & 1 & 460 \\
\hline & Sample \# 2 & 3 & 2 & 0 & 63 \\
\hline & Sample \# 3 & 3 & 3 & 1 & 460 \\
\hline \multirow{3}{*}{$\begin{array}{l}\text { B samples of } \\
\text { water of the } \\
\text { source }\end{array}$} & Sample \# 1 & 3 & 1 & 0 & 53 \\
\hline & Sample \# 2 & 2 & 0 & 0 & 23 \\
\hline & Sample \# 3 & 3 & 1 & 0 & 43 \\
\hline \multirow{3}{*}{$\begin{array}{l}\text { C samples of } \\
\text { water of the } \\
\text { village's well }\end{array}$} & Sample \# 1 & 2 & 0 & 2 & 20 \\
\hline & Sample \# 2 & 1 & 0 & 1 & 7.2 \\
\hline & Sample \# 3 & 1 & 2 & 1 & 15 \\
\hline
\end{tabular}

As Table 2 exhibits, the maximum and minimum number of colonies has been changed dramatically due to the gamma radiation that has been radiated. The maximum number of colonies was 460 for watering Through and the minimum was 63.The maximum and minimum 
Non Exposed by the ray

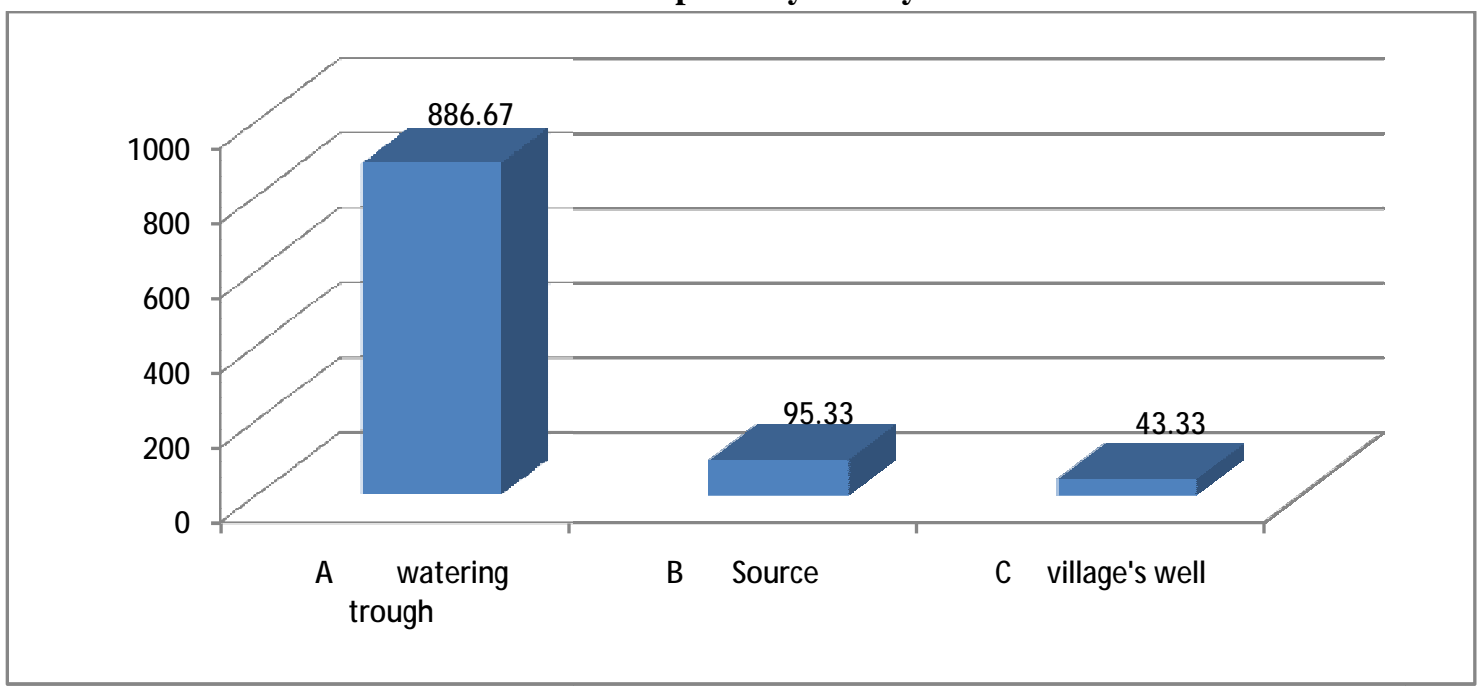

Fig. 1 Contamination level in water samples in non exposed by ray

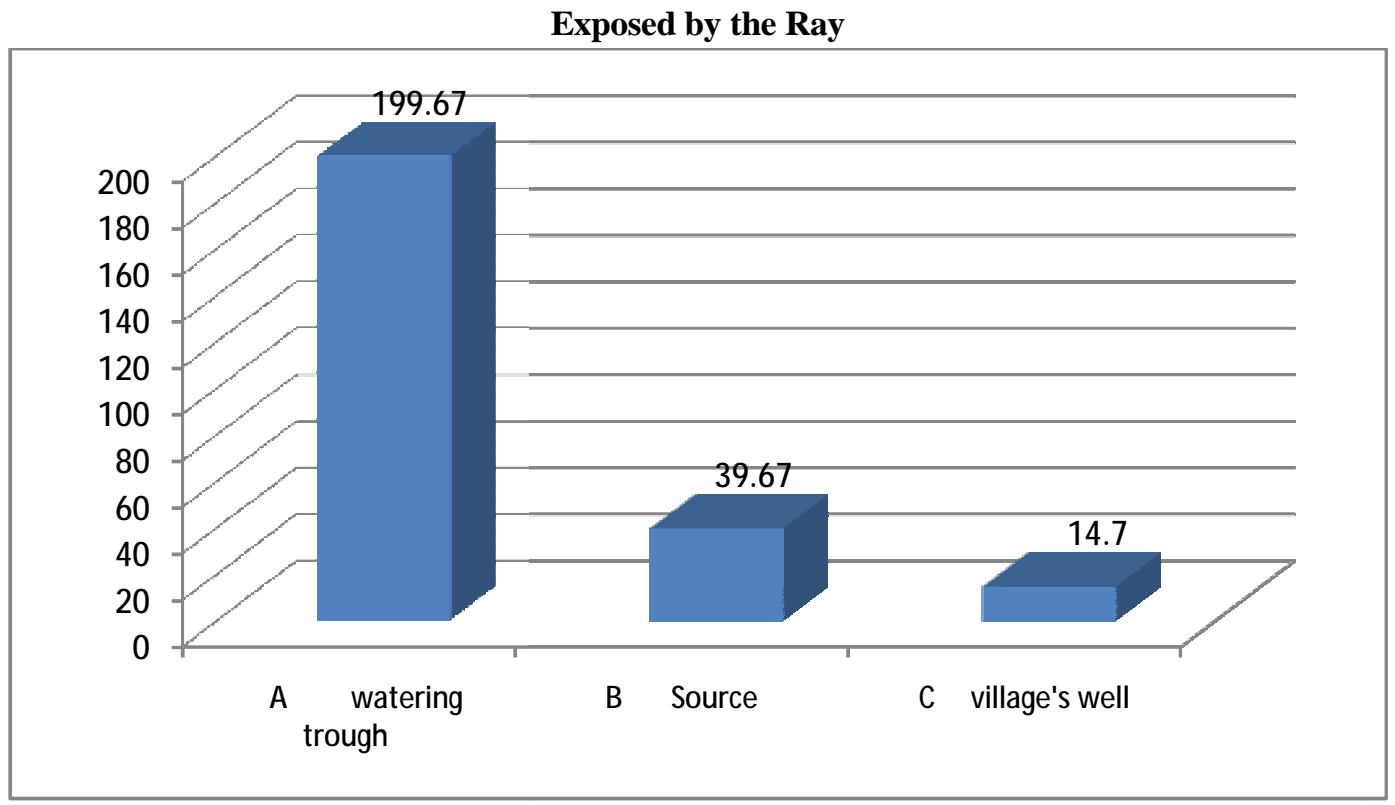

Fig. 2 Contamination level in water samples in exposed by ray

\section{Discussion}


$\delta$ Radiation is highly effective on water presented microorganisms specially $E$ coli, a summary of results are mentioned below. According to table 1, 2 maximum contamination levels was present in poultry farm destinies water samples, then in tank water and finally well water samples which had minimum contamination level.Contamination level in destiny water samples has reached from 886.67 to 199.67 (about 405 levels), in tank water from 45.33 to 39.67 and in well water sample from 43.33 to 14.7. Based on $\delta$ rediation level, bactericidal effects are different according to a study on 2016, $47 \%$ of stagnant water, $E$. coli were reduced using 28 milicurie dosage. Increasing dosage of radiation results in radiation time reduction(Smith et al. 2016).

Some researchers (Zhang Y., Yang, Zou, Chen, Ou, Zou \& Wang 2016b) investigated the disinfection of waste waters by gamma radiation using 60co gamma source and high energy electrons. It finally observed 3 logs reduction of sample microorganisms at an electron beam of $500 \mathrm{Krads}$, while at least 4 logs reduction were observed at the same time utilizing gamma radiation which, in turn, approve the obtained $p$ value of $p<0.03$.

Another study (Zevallos-Concha et al. 2016) was conducted to examine effect of gamma irradiation on coliphages, Fspecific coliphages and Escherichia coli used as viral indicators, in urban wastewater treatment plant in Tunisia. They used ${ }^{60} \mathrm{co}$ as radioactive agent and kept the laboratory temperature between 25 to $30{ }^{\circ} \mathrm{c}$. 1-9 KGy dose of radiation obtained by varying exposure time. Finally they concluded that radiation resistance depends on model micro-organism and matrix and Also E coli is deactivated much sooner than bacteriophages. The $\mathrm{p}$ value in this study was $\mathrm{p} \leq 0.05$ and D10 for raw sewage was. $06+.005$ and sewage and sludge was. 07 \pm .005 .

Shirai et al. (2016) concluded that the characteristics of the water in which the microorganisms are suspended, a significant impact on their inactivation by means of radiation was observed. In a study made (Vereschako, Tshueshova, Gorokh, Kozlov \& Naumov 2016) to inactivate using the Gamma radiation on micro-organism was investigated in which a Gamma cell 200 radiation chamber was utilized as well as a co-60 source. The average rate of irradiation was $1.4 \mathrm{KGy} / \mathrm{s}$ and a $170 \mathrm{~Gy}$ dose was used for 1-log inactivation of $E$. coli while, in another study founded by Zhang (2016), 6080 Gy radiation for $1 \log$ inactivation of $E$. coli in de-ionizing water was reported. 
Finally, Vereschako and et al proved that reduction in $E$. coli concentration has a linear relationship by the radiation dose(Vereschako et al. 2016).

Zhang Y. et al. (2016b) studied the effect of Gamma radiation of E-coli cultures combined with aeration. A bath reactor placed near a Gama cell 200 irradiator with co-60 source. The dose rate were in the range of 30-40 Gy/min applied to the sample and the concentration of final samples used of $10^{7}-10^{8} \mathrm{E}$ coli/ml. The Gamma radiation process was preceded by oxygen aeration and the inactivation efficacy of gamma irradiation was significantly improved by increasing the dissolved oxygen concentration in the suspending medium. Finally, they found, a dose of approximately 350Gy would appear to be sufficient to achieve four $\log _{10}$ units of pure culture $E$. coli inactivation in the media. Based on current investigation results, there is a possibility to use \&radiation in stagnant water disinfection which are one of the most important factors in pathogen transfer to animals and humans.

In case of routine consideration intervals and usage of higher $\delta$ radiation it is possible to obtain ideal results without any chemical and physical changes in water as well as its ionization and in the minimum time to disinfect surface water.

\section{References}

Hayati P., Rezvani A.R., Morsali A. \& Retailleau P. (2017) Ultrasound irradiation effect on morphology and size of two new potassium coordination supramolecule compounds. Ultrason Sonochem 34, 195-205.

She C., Shi G.L., Xu W., Zhou X.Z., Li J., Tian Y., Li J., Li W.H., Dong Q.R. \& Ren P.G. (2016) Effect of low-dose X-ray irradiation and Ti particles on the osseointegration of prosthetic. J Orthop Res 34, 1688-1696.

Shirai R., Miura T., Yoshida A., Yoshino F., Ito T., Yoshinari M. \& Yajima Y. (2016) Antimicrobial effect of titanium dioxide after ultraviolet irradiation against periodontal pathogen. Dent Mater J 35, 511-516.

Smith R.W., Seymour C.B., Moccia R.D. \& Mothersill C.E. (2016) Irradiation of rainbow trout at early life stages results in transgenerational effects including the induction of a bystander effect in non-irradiated fish. Environ Res 145, 26-38.

Thang K., Au K., Rakovski C. \& Prakash A. (2016) Effect of phytosanitary irradiation and methyl bromide fumigation on the physical, sensory, and microbiological quality of 
blueberries and sweet cherries. J Sci Food Agric

96, 4382-4389.

Vereschako G.G., Tshueshova N.V., Gorokh G.A., Kozlov I.G. \& Naumov A.D. (2016) Effect of External Irradiation and Immobilization Stress on the Reproductive System of Male Rats. Radiats Biol Radioecol 56, 56-63.

Vilela F.M., Oliveira F.M., Vicentini F.T., Casagrande R., Verri J.W.A., Cunha T.M. \& Fonseca M.J. (2016) Commercial sunscreen formulations: UVB irradiation stability and effect on UVB irradiation-induced skin oxidative stress and inflammation. $J$ Photochem Photobiol B 163, 413-420.

Zevallos-Concha A., Nunez D., Gasco M., Vasquez C., Quispe M. \& Gonzales G.F. (2016) Effect of gamma irradiation on phenol content, antioxidant activity and biological activity of black maca and red maca extracts (Lepidium meyenii walp). Toxicol Mech Methods 26, 6773.

Zhang T.Y., Lin Y.L., Xu B., Xia S.J., Tian F.X. \& Gao N.Y. (2016a) Effect of UV irradiation on the proportion of organic chloramines in total chlorine in subsequent chlorination. Chemosphere 144, 940.

Zhang Y., Yang C., Zou J.Z., Chen F., Ou X., Zou H.R. \& Wang Y. (2016b) Effect of lowdose focused ultrasound pre-irradiation versus microbubbles for enhancing high-intensity focused ultrasound ablation of VX2 hepatic tumor in rabbits. Nan Fang Yi Ke Da Xue Xue Bao 36, 1352-1356.

Zhu W., Liu J., Yu S., Zhou Y. \& Yan X. (2016) $\mathrm{Ag}$ loaded WO3 nanoplates for efficient photocatalytic degradation of sulfanilamide and their bactericidal effect under visible light irradiation. J Hazard Mater 318, 407-416. 


\title{
اثر اشعه كاما | | براى غير فعال كردن باكترى اشرشياكلى در آب آلوده
}

\author{
حامد اهرى ، مريم على نزاد ديزج ، سعيد پيايدارى 3 و امير على انوار 4 \\ 1 استاديار، بخش مواد غذايى، واحد علوم تحقيقات، دانشكاه آزاد اسلامى، تهران، ايران \\ 2 نمركز بيمارى هاى مزمن تنفسى، موسسه ملى تحقيقات سل و بيمارى هاى ريوى، دانشخاه علوم يزشكى شهيد بهشتى، تهران، ايران \\ 3 · بخش مواد غذايى، واحد علوم تحقيقات، دانشكاه آزاد اسلامى، تهران، ايران \\ 4 - استاديار، بخش بهداشت مواد غذايى، واحد علوم تحقيقات، دانشكاه آزاد اسلامى، تهران، ايران
}

\begin{abstract}
جكيده
جند روش مشترى براى ضد عفونى آب در اين بخش استفاده مى شود، اما با استفاده از روش ابه عنوان مثال كلر | با خطرناك توسط محصولات همراه و همجنين به تغييرات قابل توجه در بو و طعم آب منجر شود اشعه كاما به عنوان يك روش در حال ظهور است در حال حاضر توسط FAO / WHO براى آب، تصفيه خانه فاضلاب و مواد غذايى تشويق شده است باكترى متعلق به آلاينده مشترك از آب و به عنوان يك شاخص اثر بخشى اقدامات ايمنى آب، از جمله اشعه كَاما استفاده مى شود، مطالعه حاضر با هدف بررسى اثر يرتو كاما به ريشه كن كردن آلودگى هاى ميكروبى از منابع آب در صنايع غذايى انجام شده است نمونه آب از صنايع غذايى واقع در اطراف تهران، پايتخت ايران جمع آورى شد نمونه ها از سه منبع عمده اى از سيستم آب صنايع غذايى؛ خوب، مخزن و آب بازيافت جمع آورى شد و بخشى از نمونه تحت تابش با Cs137 كاما رادياتور ، دمان و نمونه درمان نشده با استفاده از روش تخمير جند لوله استاندارد براى تشخيص باكترى كلى فرم ها و شاخص MPN مورد آزمايش قرار كرفتند، محاسبه شد : يرتو كاما اثر قتل بود در كليفرمها و منجر به كاهش قابل توجه در شاخص نمونه آب تصفيه شده در مقايسه با آنهايى كه درمان نشده با حند تغيير در دوز تابش، انتظار مى رود براى كاشت رادياتور كاما قابل حمل به

$$
\text { درمان آب در بخش صنايع غذايى. }
$$$$
\text { كلمات كليدى :صنايع غذايى، كاما تابش، تصفيه آب، كلى فرم }
$$
Saaa4824@gmail.com :
\end{abstract}

